\title{
Kewenangan Diskresi Kepolisian Republik Indonesia dalam Penegakan Hukum Pidana
}

\author{
Ni Ketut Sari Adnyani ${ }^{{ }^{*}}$ \\ ${ }^{1}$ Universitas Pendidikan Ganesha, Indonesia
}

\section{A R T I C L EI N F 0}

\section{Article history:}

Received 18 July 2021

Accepted 03 November 2021

Available online 01

December 2021

Kata Kunci:

Diskeresi; Polisi;

Kewenangan; Tindak

Pidana

Keywords:

Discertion; Police;

Authority; Criminal Act

\begin{abstract}
A B S T R A K
Penelitian ini bertujuan untuk mengkaji dan menganalisis kewenangan diskresi kepolisian dalam fungsi dan tugas kepolisian, dan menganalisis implementasi kewenangan diskresi kepolisian dalam penanganan tindak pidana. Jenis penelitian yaitu penelitian normatif dengan pendekatan peraturan perundang-undangan dan pendekatan konseptual. Sumber bahan hukum primer. Teknik analisis yang digunakan teknik analisis hermeneutika hukum. Hasil penelitian menunjukkan bahwa kewenangan diskresi kepolisian dilakukan dengan cara melakukan tindakan kepolisian lainnya yang dapat dipertanggungjawabkan. Lebih jauh, implementasi kewenangan diskresi Kepolisian dalam penanganan tindak pidana, tindakan Polisi itu cenderung dihargai oleh publik, negatifnya banyak kalangan masyarakat yang tidak mengetahui kewenangan diskresi yang dimiliki polisi. Pembinaan kemampuan profesi pejabat Kepolisian Negara Republik Indonesia dapat diselenggarakan melalui pembinaan etika profesi dan pengembangan pengetahuan serta pengalamannya di bidang teknis Kepolisian.
\end{abstract}

\section{A B S T R A C T}

This study aims to examine the discretionary authority of the Police in the functions and duties of the Police and analyze the implementation of the Police's discretionary authority in handling criminal acts. The type of research is normative research with a statutory and conceptual approach-sources of primary legal materials. The analytical technique used is the legal hermeneutic analysis technique. The study results showed that the police discretionary authority is carried out by carrying out other accountable police actions. Moreover, with the police discretionary authority in handling crimes, police actions tend to be appreciated by the public. The negative thing is that many people do not know the discretionary authority they have. The professional capability development of the officers of the State Police of the Republic of Indonesia can be carried out through the development of professional ethics and the development of knowledge and experience in the technical field of the Police.

\footnotetext{
* Corresponding author.

E-mail addresses: niktsariadnyani@gmail.com
} 


\section{Pendahuluan}

Sistem peradilan pidana dapat dilihat bahwa serangkaian penegakan hukum mulai dari proses penyidikan, penuntutan, putusan hakim dalam pengadilan sampai dengan lembaga pemasyarakatan. Tata urutan mengenai proses penegakan hukum tersebut, nampak bahwa kepolisian merupakan instansi pertama yang melakukan proses awal dalam penegakan hukum pidana (Nugrahanto, 2013).

Setiap warganegara mempunyai hak untuk mendapatkan jaminan kepastian hukum yang secara khusus oleh POLRI (Polisi Republik Indonesia) sebagai lembaga penegak hukum pada awal proses penegakan hukum pidana. Dilihat dari sisi sebagai penegakan hukum, sesuai Pasal 13 Undang-Undang No.2 Tahun 2002 tentang Kepolisian Republik Indonesia mengatur mengenai tugas POLRI, yaitu: (1) mempunyai tugas untuk memelihara keamanan dan ketertiban masyarakat; (2) menegakkan hukum; dan (3) memberikan perlindungan, pengayoman dan pelayanan kepada masyarakat. Oleh karenanya, tugas pokok dan fungsi Polri, selain sebagai pengayom masyarakat juga sebagai penegak hukum (Anshar \& Setiyono, 2020).

Penegakkan hukum di manapun di seluruh dunia membutuhkan Polisi untuk mewakili negara dalam menerapkan dan menjaga penerapan hukum pada seluruh sektor kehidupan masyarakat. Tidak satupun negara tanpa polisi, sekalipun tugas dan fungsinya berbeda-beda antara satu negara dengan negara lainnya. Kepolisian Republik Indonesia dalam melaksanakan peran dan fungsi kepolisian di seluruh wilayah Republik Indonesia mengembangkan "Integrated System of Policing" (Sistem Kepolisian Terpadu). Kepolisian Negara Republik Indonesia atau yang sering disingkat dengan Polri dalam kaitannya dengan Pemerintahan adalah salah satu fungsi pemerintahan negara di bidang pemeliharaan keamanan dan ketertiban masyarakat, penegakan hukum, perlindungan, pengayoman, dan pelayanan kepada masyarakat, yang bertujuan untuk mewujudkan keamanan dalam negeri yang meliputi terpeliharanya keamanan dan ketertiban masyarakat, tertib dan tegaknya hukum, terselenggranya perlindungan, pengayoman, dan pelayanan kepada masyarakat, serta terbinanya ketentraman masyarakat dengan menjunjung tinggi hak azasi manusia (Haji \& Gunarto, 2018).

Tugas dan fungsi kepolisian sangat berbeda dengan kepolisian di Indonesia, yang bertugas dan berfungsi sebagai Penegak hukum, penjagaan keamanan dan ketertiban masyarakat (Kamtibmas) (Aziz, 2011), serta pelayanan dan pengayoman masyarakat adalah tugas pokok polisi sebagai profesi mulia, yang aplikasinya harus berdasarkan undang-undang yang berlaku dan hak azasi manusia. Penegakkan hukum tidak bisa terlepas dari hak asasi manusia (Najwan, 2010).

Pekerjaan Polisi adalah penegakan hukum in optima forma, Polisi adalah hukum yang hidup. Melalui Polisi janji-janji dan tujuan hukum untuk mengamankan serta melindungi masyarakat menjadi kenyataan (Rahardjo, 2009). Berdasarkan Pasal 2 Undang-Undang Nomor 2 Tahun 2002 tentang Kepolisian Negara Republik Indonesia (selanjutnya disebut dengan istilah UU No. 2 Tahun 2002, maka fungsi kepolisian adalah salah satu fungsi pemerintahan negara di bidang pemeliharaan keamanan dan ketertiban masyarakat, penegakan hukum, perlindungan, pengayoman, dan pelayanan kepada masyarakat.

Fungsi kepolisian dalam menjaga keamanan dan ketertiban masyarakat harus didukung dengan otoritas hukum. Salah satunya adalah Peraturan Kepala Kepolisian Negara Republik Indonesia Nomor 7 Tahun 2009 Tentang Sistem Laporan Gangguan Keamanan dan Ketertiban Masyarakat (selanjutnya disingkat Perkap No. 7 Tahun 2009). Berdasarkan Pasal 1 Angka 3 Perkap No. 7 Tahun 2009, maka yang dimaksud keamanan dan ketertiban masyarakat (selanjutnya disingkat Kamtibmas) adalah suatu kondisi dinamis masyarakat sebagai salah satu prasyarat terselenggaranya proses pembangunan nasional dalam rangka tercapainya tujuan nasional yang ditandai oleh terjaminnya keamanan, ketertiban, dan tegaknya hukum, serta terbinanya ketenteraman, yang mengandung kemampuan membina serta mengembangkan potensi dan kekuatan masyarakat dalam menangkal, mencegah, dan menanggulangi segala bentuk pelanggaran hukum dan bentuk-bentuk gangguan lainnya yang dapat meresahkan masyarakat (Priyantoko, 2017). 
Menafsirkan hukum menjadi jembatan antara hukum dengan tujuan-tujuan sosial yang diinginkan. Pada praktiknya di lapangan, polisi sering dilihat sebagai yang sehari-harinya menafsirkan hukum. Penafsiran hukum juga memungkinkan diatasinya konflik antara hukum dan ketertiban. Seorang Polisi misalnya, tidak akan melaksanakan suatu ketentuan hukum, kalau pelaksanaannya justru akan menimbulkan ketidaktertiban dalam masyarakat (Said, 2012). Kondisi tersebut menunjukan pelaksanaan tugas Kepolisian dan Kejaksaan tidak selalu sama benar dengan yang tertera dalam peraturan perundang-undangan. Polisi dihadapkan pada persoalan harus menentukan pilihan berkenaan dengan masalah diskresi untuk memutuskan suatu persoalan yang dihadapi.

Undang Undang Kepolisian Nomor 2 Tahun 2012, Pasal 18 telah disebutkan dalam satu pasalnya tentang salah satu bentuk kewenangan yang legal berupa diskresi kepolisian, dimana kepolisian berwenang melakukan tindakan lain yang bertanggung jawab. Kepolisian Republik Indonesia sebagai institusi telah melakukan diskresi, hal ini dimaksudkan lembaga kepolisian pun dapat bekerja secara profesionel sebagai pengayom masyarakat.

Kewenangan bertindak berdasarkan hukum pada hakikatnya dinilai bertentangan dengan pemberian diskresi kepada Polisi. Diskresi di satu sisi, dinilai meniadakan kepastian terhadap sesuatu yang akan terjadi, di sisi lain menjamin kepastian hukum menjadi sedangkan salah satu fungsi hukum. Tindakan diskresi yang diputuskan oleh Polisi dalam menghadapi persoalan hukum di lapangan secara langsung pada saat itu juga dan tanpa meminta petunjuk atau keputusan dari atasannya adalah diskresi yang bersifat individual. Sebagai contoh untuk menghindari terjadinya penumpukan arus lalu lintas di suatu ruas jalan, petugas Kepolisian member syarat untuk terus berjalan kepada pengemudi kendaraan meskipun saat itu lampu mengatur lalu lintas berwarna merah.

Poin penting dari kajian ini adalah melihat tolak ukur penilaian wewenang penggunaan kewenangan diskresi oleh Polisi dalam proses pemeriksaan perkara pidana, stresingnya pada model pengawasan atau kontrol terhadap penggunaan diskresi yang diperankan oleh hakim dalam proses penegakan hukum pidana, sebab selama ini terkesan bahwa penggunaan diskresi oleh Polisi maupun Jaksa lepas dari pengawasan maun kontrol dari lembaga yang berwenang sehingga diskresi dapat digunakan tidak tidak wajar atau salah dimanfaatkan dalam proses penegakan hukum tindak pidana. Oleh sebab itu perlu dilakukan penelitian yang tujuannya adalah untuk mengetahui kewenangan diskresi Kepolisian Republik Indonesia dalam penegakan hukum pidana.

Tujuan kajian artikel ini adalah untuk mengkaji dan menganalisis diskresi kepolisian dalam fungsi dan tugas kepolisian dan penegakan hukum pidana oleh Kepolisian Republik Indonesia. Berkenaan dengan kewenangan diskresi Kepolisian RI, penting dipahami terlebih dahulu mengenai tugas Kepolisian, yang terdiri dari tugas pokok institusi POLRI maupun tugas tambahan institusi POLRI.

Mewujudkan tujuan Negara, maka dibentuk aparat penyelenggara Negara yang diberikab kekuasaan untuk memerintah. Berimplikasi terhadap pelaksanaan kekuasaan Negara dibatasi dengan konstitusi. Sebagaimana telah diuraikan sebelumnya, tugas pokok institusi POLRI berdasarkan Pasal 13 UU No.2/2002, menguraikan bahwa untuk memelihara keamanan dan ketertiban masyarakat, menegakkan hukum, dan memberikan perlindungan, pengayoman dan pelayanan kepada masyarakat. Fungsi keamanan dan pertahanan merupakan dua fungsi yang berbeda. Fungsi pertahanan dan keamanan tidak dapat disatukan, karena fungsi pertahanan (defence) merupakan fungsi khusus militer yang berperan untuk bertempur mempertahankan kedaulatan Negara dari berbagai pihak yang mengancam dan/atau mengganggu keamanan negara. Sedangkan fungsi keamanan (security) merupakan fungsi khas kepolisian universal yang berperan aktif untuk melindungi dan melayani masyarakat.

Kondisi institusi Kepolisian saat ini, di samping melaksanakan tugas pokok juga melaksanakan tugas-tugas sosial politik. Dengan demikian secara langsung maupun tidak langsung keterlibatannya dengan politik akan mengakibatkan keberpihakan. Padahal sesuai dengan tugas pokoknya sebagai penegak hukum harus bersikap adil dan tidak memihak. Kepolisian Negara Republik Indonesia membutuhkan dukungan keterlibatan masyarakat dalam 
menciptakan keamanan dan ketertiban umum. Diskresi membolehkan anggota kepolisian untuk menerapkan perbedaan dalam menangani suatu peristiwa. Hubungannya dengan pengkajian diskresi Kepolisian, kajian difokuskan ruang lingkup kewenangan diskresi dapat diberikan oleh petugas Kepolisian RI.

\section{Metode}

Penelitian ini adalah penelitian hukum (doctrinal research) bertujuan untuk memberikan eksposisinya yang bersifat sistematis mengenai suatu aturan hukum berkenaan kewenangan diskresi Kepolisian Republik Indonesia dalam penegakan hukum pidana tidak menutup kemungkinan juga mencakup frediksi perkembangan suau aturan hukum intenasional yang mempengaruhi dinamika pembangunan hukum di Indonesia pada masa mendatang (Susanti \& Efendi, 2014). Penelitian ini merupakan penelitian evaluatif dan preskriptif. Dikatakan penelitian ini bersifat evaluatif karena penelitian ini memberikan analisis mendalam tentang diskresi kepolisian dalam fungsi dan tugas kepolisian dan implementasi kewenangan diskresi kepolisian dalam penanganan tindak pidana.. Sifat preskriptif dari penelitian ini dapat dilihat bahwa penelitian ini juga memberikan solusi yang tepat berdasarkan prinsip-prinsip hukum yang termaktub dalam beberapa ketentuan hukum khususnya di bidang kewenangan diskresi Kepolisian RI dalam penegakan hukum pidana berdasarkan substansi Pasal 18 UU No 2 Tahun 2002.

Penelitian ini menggunakan pendekatan statuta dan pendekatan konseptual. Pendekatan statuta digunakan untuk menelaah semua undang-undang dan regulasi yang bersangkut paut dengan isu hukum yang sedang diteliti dalam hal ini berkaitan dengan kewenangan diskresi Kepolisian Republik Indonesia dalam penegakan hukum pidana. Pendekatan statuta tersebut juga mencari ratio legis dan dasar ontologinya lahirnya peraturan perundang-undangan sehingga dapat memahami kandungan filosofis yang ada di balik undang-undang tersebut (Marzuki, 2005). Konsep hukum adalah konsep konstruktif dan sistematis yang digunakan untuk memahami sebuah aturan (Arief, 2008). Penelitian ini adalah mengkaji doktrin, asas, dan konsep dalam ilmu hukum yang berkaitan dengan masalah hukum yang menjadi pokok permasalahan yang peneliti kaji yaitu kewenangan diskresi Kepolisian Republik Indonesia dalam penegakan hukum pidana. Pemahaman akan doktrin dan pandangan tersebut menjadi pedoman bagi peneliti dalam membangun suatu argumentasi hukum dalam memecahkan isu hukum yang dihadapi.

Setelah semua bahan hukum terkumpul yang relevan dengan permasalahan, semua bahan-bahan hukum baik bahan hukum primer, bahan hukum sekunder maupun non hukum dilakukan inventarisasi, identifikasi dan klasifikasi untuk menemukan hukum sesuai dengan permasalahan yang diteliti (Syamsudin, 2007). Analisa bahan hukum dengan teknik hermeneutika hukum, apabila dikaitkan dengan penegakan hukum progresif tidak dapat dilepaskan dari idiologi yang mendasari perumusan dan penegakan hukum. Selanjutnya diilustrasikan dengan menggunakan teknik deskriptif analitis melalui pendekatan kualitatif terhadap bahan-bahan hukum dengan mengabstraksikan peraturan perundang-undangan yang ada agar dapat menemukan norma hukum yang terkandung dalam setiap peraturan perundangundangan terkait permasalahan perlindungan hukum terhadap kewenangan diskresi Kepolisian Republik Indonesia dalam penegakan hukum pidana. Penjabaran terhadap bahan hukum yang sudah terkumpul kemudian dianalisis sesuai sifatnya, yaitu mulai dari deskriptif, evaluatif dan preskriptif berkenaan dengan fokus permasalahan dan dicari penyelesaiannya.

\section{Hasil dan Pembahasan}

Sebelum ini, telah ada beberapa penelitian yang menggngkat tema mengenai tugas dan fungsi polisi sebagai penegak hukum. Ada yang membahasmengenai tugas dan fungsi kepolisian dalam perannya sebagai penegak hukum menurut undang-undang nomor 2 tahun 2002 tentang kepolisian (Tasaripa, 2013). Penelitan ini menggunakan pendekatan normatif untuk menjelaskan peran polisi menurut undang-undang nomor 2 tahun 2002. Kemudian mengenai fungsi kepolisian negara dalam pemeliharaan keamanan dan ketertiban pada masyarakat kota 
sengkang Kabupaten Wajo (Guntur,2017), merupakan kajian Implementasi dari fungsi kepolisian negara di Kabupaten Wajo; selanjutnya Raharjo dan Angkasa (2011), mengangkat tema Profesionalisme Polisi dalam Penegakan Hukum, yang mengedepankan Etika Polisi sebagai hukum dalam masyarakat ekslusif. Menggunakan kewenangan diskresi kepolisian, makalah ini mengkaji fungsi dan tugas kepolisian dengan kewenangan diskresi yang diberikan kepadanya dalam rangka memelihara ketertiban dan menjamin keamanan umum. Relevansi kewenangan diskresi kepolisian dengan HAM dapat ditinjau dari Perspektif HAM, KUHAP dan UU No.2 Tahun 2002 dalam rangka penegakan hak asasi manusia dapat dilihat pada Table 1.

Tabel 1. Relevansi kewenangan diskresi kepolisian dengan HAM

\begin{tabular}{lllrl}
\hline No & \multicolumn{1}{c}{$\begin{array}{l}\text { Undang-Undang } \\
\text { Nomor 39 Tahun }\end{array}$} & \multicolumn{2}{c}{ KUHAP } & \multicolumn{2}{c}{ UU No.2/2002 tentang Kepolisian } \\
1999 tentang HAM
\end{tabular}

Sumber: Diadaptasikan dari pengaturan kewenangan diskresi Kepolisian (2021)

\section{Kewenangan diskresi kepolisian dalam fungsi dan tugas kepolisian}

Berdasarkan perkembangan pengaturan kewenangan diskresi Kepolisian di atas, di Indonesia sendiri wewenang kepolisian secara umum telah diatur di dalam Undang-Undang Nomor 2 Tahun 2002 tentang Kepolisian. Sementara dalam proses penegakan hukum pidana diatur tersendiri melalui Undang- Undang Nomor 8 Tahun 1981 tentang Hukum Acara Pidana, atau biasa disebut dengan Kitab Undang-Undang Hukum Acara Pidana (KUHAP). Adapun bila dikaitkan dengan kewenangan kepolisian dalam penanganan konflik, telah diatur khusus dalam UU Penanganan Konflik Sosial, beserta peraturan internal POLRI yakni PROTAP POLRI Nomor 1/X/2010 tentang Penanggulangan Anarki.

Kepolisian dalam perspektif kebijakan kriminal dan Kepolisian dalam perspetif Sistem Peradilan Pidana (SPP) keduanya tidak dapat dilepaspisahkan karena pada hakikatnya sistem peradilan pidana merupakan bagian dari kebijakan kriminal. Sistem peradilan pidana pada dasarnya merupakan sistem penegakan hukum pidana yang bertujuan untuk menanggulangi kejahatan (Faisol, 2003).

Kewenangan dalam penerapan Diskresiini didasarkan pada pertimbangan keperluannya untuk tugas kewajiban (Flichtmassiges Ermessen). Substansi Pasal 18 ayat (1) Undang-undang Kepolisian Nomor 2 Tahun 2002 merupakan konsep kewenangan kepolisian. Pelaksanaan "diskresi" sebagaimana dimaksud pada ayat (1) yaitu selain asas keperluan, tindakan diskresi tetap harus sesuai dan memperhatikan peraturan perundang-undangan serta kode etik profesi Kepolisian Negara Republik Indonesia. 
Dilihat dari perspektif legalitas hukum, tugas serta kewenangan Kepolisian secara fungsional tidak lain berupa penerapan atau penegakan hukum, dengan demikian, Polisi menjadi penjaga status quo dari hukum. Hal ini mempunyai konsekuensi, bahwa apa yang dilakukan oleh Polisi tidak akan menyimpang dari seperangkat aturan bagi penegakan hukum itu, seperti perundang-undangannya sendiri, doktrin-doktrinnya, serta asas-asasnya yang lazim diterima dalam dunia hukum pidana. Tidak heran kalau kemudian muncul sebutan, bahwa Polisi itu adalah "hamba hukum", "aparat penegak hukum", dan sebagainya (Ali, 2007).

Situasi atau kondisi-kondisi yang mengharuskan Polisi menerapkan kebijakan (diskresi) tersebut disebabkan karena beberapa hal diantaranya adalah:

1) Adanya suatu pilihan yang diperhadapkan bagi pejabat untuk memilih berdasarkan putusan yang rasional dan mendasar. Namun, setiap pilihan itu mengandung arti bahwa memang ada beberapa alternatif dimana antithesis pada diskresi itu adalah situasi dimana hukum memberikan suatu solusi yang tepat dan benar terhadap suatu kasus.

2) Alasan penggunaan diskresi adalah masalah tata bahasa hukum yang tidak kongkrit.

3) Terdapat celah atau kekosongan (legal gap) suatu aturan hukum dipandang sebagai sebuah sumber penggunaan diskresi karena penafsir/interpreter harus membuat sebuah pilihan diantara sekian alternatif. Masalah legal gap sering terkait dengan indeterminasi semantik.

4) Kontradiksi atau inkonsistensi diantara dua aturan hukum bila "incompatible legal effects are attached to the same factual conditions" (efek hukum yang tidak sepadan diberikan pada kondsi faktual yang sama).

Pedoman dalam mengambil keputusan menerapkan diskresi kepolisian, batasan dalam menerapkan diskresi dijelaskan dalam Pasal 16 ayat 2 Undang-Undang Nomor 2 tahun 2002 disebutkan bahwa tindakan dari penyelidik untuk kepentingan penyelidikan dengan 5 (lima) persyaratan sebagai berikut:

1) Tidak bertentangan dengan suatu aturan hukum;

2) Selaras dengan kewajiban hukum yang mengharuskan dilakukannya tindakan jabatan;

3) Tindakan itu harus patut dan masuk akal dan termasuk dalam lingkungan jabatannya;

4) Atas pertimbangan yang layak berdasarkan keadaan memaksa;

5) Menghormati hak asasi manusia.

Berdasrkan pada kondisi-kondisi tersebut di atas dapat dipahami bahwa permasalahan diskresi tersebut terjadi, karena tidak ada pedoman atau kalau ada juga pedoman yang digariskan terbaca sangat abstrak dan susah diterapkan. Diskresi Kepolisian harus diterapkan dalam pelaksanaantugas Kepolisian Sebagimana diamanatkan dalam pasal 13 UU No 2 tahun 2002 tentang Kepolisian Negara Republik Indonesia, tugas Polri adalah memelihara keamanan dan ketertiban masyarakat, menegakkan hukum dan memberi perlindungan, pengayoman dan pelayanan kepada masyarakat. Oleh karena itu, dalam praktik penerapan diskresi oleh Polisi mau Jaksa sangat tergantung pada subyektivitas yang bersangkutan. Jika penegak hukum dimaksud menghayati nilai-nilai moral atau etika sebagai seorang Polisi maupun Jaksa, maka penerapan diskresi akan melahirkan rasa keadilan dan ketenteraman dalam masyarakat. Sebaliknya, jika Polisi yang tidak berpegang pada nilai-nilai moral, dan etika, maka penerapan diskresi akan melahirkan kesewenang-wenangan.

Sesuai dengan kewenangannya Polri dapat melakukan upaya Kepolisian sebagaimana diatur dalam Undang-Undang yaitu penyeldikan dan penyidikan yang meliputi pemanggilan, pemeriksaan, penangkapan, penahanan, penggeledahan dan penyitaan. Namun sebagaimana sifat masyarakat yang selalu berubah dan mengalami perubahan sebagaimana disebutkan di atas, terkadang petugas Kepolisian harus mengambil tindakan baik dalam rangka penyelidikan maupun penyidikan tetapi hal tersebut belum diatur dalam Undang-Undang. Oleh karenanya untuk memelihara ketertiban umum, dalam keadaan tertentu anggota Polri perlu melakukan tindakan sesuai dengan penilaiannya sendiri.

Diskresi memang diperlukan karena lingkup aturan tidak menjangkau secara komprehensif dan detail bagaimana setiap Pejabat dapat menjalankan tugas, wewenang dan tanggungjawabnya di lapangan, sehingga diperlukan ada pertimbangan dan kebijakan subyektif dari Pejabat publik bersangkutan demi kelancaran tugas-tugasnya. Urgen untuk 
dipertimbangkan bahwa diskresi ini dapat dilakukan dengan benar dengan mempertimbangkan segala aspek atau hal-hal di atas disertai etika yang baik seperti yang diuraikan sebelumnya. Oleh karena itu, dengan diskresi ini makatindakan yang diambil oleh Polisi harus benar secara hukum.

Tugas pokok yang diemban oleh institusi Polri adalah sebagaimana yang telah diatur dalam Pasal 13 UU No. 2 Tahun 2002, yaitu:(a) memelihara keamanan dan ketertiban masyarakat (b) menegakkan hukum; dan (c) memberikan perlindungan, pengayoman, dan pelayanan kepada masyarakat. Ketiga tugas pokok tidak bersifat hirarki melainkan memiliki posisi yang sama pentingnya. Substansi tugas Polri untuk memelihara keamanan dan ketertiban bersumber dari kewajiban Polri untuk menjamin keamanan umum (Pudi, 2007). Tugas pokok Polri tersebut terkait dengan penegakan hukum bersumber dari ketentuan peraturan perundang-undangan yang memuat tugas Polri dalam kaitannya dengan peradilan pidana.

\section{Implementasi kewenangan diskresi kepolisian dalam penanganan tindak pidana}

Dilihat sebagai suatu proses kebijakan, penegakan hukum pidana pada hakekatnya merupakan penegakan kebijakan, (Felisiano \& Paripurna, 2010), melalui beberapa tahap yaitu:

1) Tahap formulasi, yaitu tahap penegakan hukum in abstracto oleh badan pembuat undangundang. Tahap ini pula disebut tahap kebijakan legislative.

2) Tahap aplikasi, yaitu tahap penerapan hukum pidana oleh aparat-aparat penegak hukum mulai dari kepolisian sampai pengadilan. Tahap kedua ini dapat pula disebut tahap kebijakan yudikatif.

3) Tahap eksekusi, yaitu tahap pelaksanaan hukum pidana secara konkret oleh aparat-aparat pelaksana pidana. Tahap ini disebut tahap kebijakan eksekutif atau administratif.

Polri juga memiliki kewenangan melakukan tindakan lain menurut hukum secara bertanggung jawab. Kewenangan tersebut merupakan kewenangan Polri dalam rangka proses pidana selaku penyelidik dan penyidik yang diatur dalam Pasal 5 ayat (1) huruf a angka 4 dan Pasal 7 ayat (1) huruf j KUHAP. Dalam rangka menyelenggarakan tugas di bidang proses pidana, POLRI berwenang untuk mengadakan tindakan lain dalam bentuk tindakan penyelidikan dan penyidikan yang dilaksanakan sebagai berikut:

1) tidak bertentangan dengan suatu aturan hukum;

2) selaras dengan kewajiban hukum yang mengharuskan tindakan tersebut dilakukan;

3) harus patut, masuk akal, dan termasuk dalam lingkungan jabatannya;

4) pertimbangan yang layak berdasarkan keadaan yang memaksa; dan

5) menghormati hak asasi manusia.

Beberapa perundang-undangan yang dapat dijadikan dasarhukum penerapan diskresi, khususnya dalam proses penegakan hukum pidana, antara lain adalah Undang-Undang Nomor 2 Tahun 2002 tentang Kepolisian,

1) Pasal 15

(2) Kepolisian Negara Republik Indonesia sesuai dengan peraturan perundang-undangan lainnya berwenang melaksanakan kewenangan lain yang termasuk dalam lingkup tugas kepolisian.

2) Pasal 16

(1) dalam rangka menyelenggarakan tugas di bidang proses pidana, Kepolisian Negara Republik Indonesia berwenang untuk: l. mengadakan tindakan lain menurut hukum yang bertanggung jawab.

2) Tindakan lain sebagaimana dimaksud dalam ayat (1) huruf l adalah tindakan penyelidikan dan penyidikan yang dilaksanakan jika memenuhi syaratsebagai berikut:

a. tidak bertentangan dengan suatu aturan hukum;

b. selaras dengan kewajiban hukum yang mengharuskan tindakan tersebut dilakukan;

c. harus patut, masuk akal, dan termasuk dalam lingkungan jabatannya;

d. pertimbangan yang layak berdasarkan keadaan yang memaksa; dan

e. menghormati hak asasi manusia. 
3) Pasal 18

(1) Undang-Undang Nomor 2 Tahun 2002 tentang Kepolisian menyebutkan bahwa untuk kepentingan umum, pejabat Kepolisian Negara Republik Indonesia dalam melaksanakan tugas dan wewenangnya dapat bertindak menurut penilaiannya sendiri.

(2) Pelaksanaan ketentuan sebagaimana dimaksud dalam ayat (1) hanya dapat dilakukan dalam keadaan yang sangat perlu dengan memperhatikan peraturan perundang-undangan, serta Kode Etik Profesi Kepolisian Negara Republik Indonesia.

Tujuan dari pelaksanaan diskresi ialah melancarkan penyelenggaraan pemerintahan, mengisi kekosongan hukum, memberikan kepastian hukum, dan mengatasi stagnasi pemerintahan dalam keadaan tertentu guna kemanfaatan dan kepentingan umum. Dalam melaksanakan diskresi pejabat pemerintah harus memenuhi syarat dalam menggunakan kewenangan diskresi, yaitu sesuai dengan tujuan dari diskresi, tidak bertentangan dengan ketentuan peraturan perundang-undangan, sesuai dengan asas-asas umum pemerintahan yang baik, berdasarkan alasan-alasan yang objektif, tidak menimbulkan konflik kepentingan dan dilakukan dengan itikad yang baik.

Diskresi hanya dapat dilakukan oleh Pejabat Pemerintahan yangberwenang, salah satunya ialah Kepolisian. Peranan Kepolisian dalam penegakan hukum dapat ditemukan didalam perundang-undangan Nomor 2 tahun 2002 Tentang Kepolisian Negara Republik Indonesia. Dalam menjalankan proses diskresi yang tidak dapat digunakan secarasembarangan wewenang tersebut oleh pihak kepolisian, dimana diskresi harus digunakan dengan alasan yang rasional dan logis, namun tetap selektif dan proposional (Demawan, 2015). Ada tiga landasan diskresi yakni:

1) Pembuat Diskresi harus mempunyai wewenang menurut hukum, tanpa wewenang, suatu diskresi adalah tindakan sewenang-wenang;

2) Tujuan diskresi tidak boleh bertentangan dengan hukum;

3) Kebebasan dalam diskresi adalah kebebasan memilih (freedom of choice) berdasarkan masalah yang dihadapi yang berada dalam lingkungan landasan pertama dan kedua.

Memperhatikan landasan diatas, maka sesungguhnya unsur legality dalam diskresi sama sekali tidak boleh diabaikan. Kebebasan (freedom of choice) ada pada pilihan agar mencapai manfaat sebesar-besarnya tanpa bertentangan dengan hukum.

Diskresi adalah wewenang dari aparat penegak hukum yang menangani kasus tindak pidana untuk mengambil tindakan meneruskan perkara atau mengambil perkara tindakan meneruskan perkara atau menghentikan perkara, mengambil tindakan tertentu sesuai dengan kewenangan yang dimilikinya (Loraine dan Nicola, 2003).

Tugas polisi sebagai penyidik dalam sistem peradilan pidana menempatkannya dalam jajaran paling depan, sehingga polisi dituntut untuk bisa menyeleksi atau memilah-milah perkara mana yang pantas untuk diajukan ke pengadilan atau tidak berdasarkan peraturan perundang-undangan (Rahardjo, 2006).

Berdasarkan hal tersebut maka apabila berbicara soal diskresi Kepolisian dalam sistem peradilan pidana, maka akan ditemukan suatu hubungan antar hukum, diskresi, kepolisian, penyidikan, dan sistem peradilan pidana. Polisi sebagai penegak hukum pidana diharapkan mampu menggunakan kewenangannya untuk kepentingan terbaik apabila berhadapan dengan hukum. Penegakan hukum pidana dengan kewenangan diskresi Kepolisian Republik Indonesia, dalam implementasinya megutamakan pendekatan keadilan restoratif, yaitu penyelesaian perkara tindak pidana dengan melibatkan pelaku, korban, keluarga pelaku/korban dan pihak lain yang terkait untuk bersama-sama penyelesaian yang adil dengan menekankan pemulihan kembali pada keadaan semula dan bukan pembalasan.

\section{Simpulan dan Saran}

Kewenangan diskresi kepolisian sangat penting dalam suatu penegakan hukum, karena salah satu tugas pokok pejabat jabat Kepolisian Negara Republik Kepolisian dalam proses hukum adalah mengadakan tindakan lain menurut hukum Negara Republik Indonesia yang bertanggung jawab. Tindakan lain berdasarkan undang-undang memiliki sebagaimana 
dimaksud dalam pasal 16 wewenang umum Kepolisian. ayat (1) Undang-undang Nomor 2 Tahun Diskresi dapat diartikan sebagai 2002 tentang Kepolisian Negara Republik siasat kebijaksanaan, sedangkan diskresi Indonesia adalah tindakan penyelidikan Kepolisian adalah merupakan suatu dan penyidikan yang dilaksanakan jika kekuasaan atau kewenangan yang memenuhi syarat sebagai berikut:diberikan oleh Undang-undang atau atas a. tidak bertentangan dengan suatu aturan kuasa Undang-undang untuk bertindak hukum; b. selaras dengan kewajiban berdasarkan pertimbangan atau keyakin-hukum yang mengharuskan tindakan an sendiri dan tindakan mana lebih tersebut dilakukan; c. harus patut, masuk bersifat moral daripada bersifat umum. akal, dan termasuk dalam lingkungan Secara praktis kewenangan doskresioner jabatannya; d. pertimbangan yang layak administrasi negara yang kemudian berdasarkan keadaan yang memaksa; melahirkan peraturan kebijaksanaan, dan e. menghormati hak asasi manusia. Implementasi kewenangan diskresi Kepolisian dalam penanganan tindak pidana adalah kewenangan diskresi tersebut diatur dalam pasal 18 Undang Undang Nomor 2 Tahun 2002, tindakan Polisi itu cenderung dihargai oleh publik, negatif banyak kalangan masyarakat yang tidak mengetahui kewenangan diskresi yang dimiliki polisi terhadap pelaku tindak pidana. Pejabat Kepolisian Negara kewajiban hukum yang megharuskan Republik Indonesia dalam melaksanakan tugas dan wewenangnya harus memiliki patut, masuk akal, dan termasuk dalam kemampuan profesi. Pembinaan kemampuan profesi pejabat Kepolisian Negara Republik Indonesia dapat diselenggarakan melalui pembinaan etika profesi dan pengembangan pengetahuan serta pengalamannya di bidang teknis Kepolisian melalui pendidikan, pelatihan dan penugasan secara berjenjang dan berlanjut, sehingga sikap dan perilaku pejabat kepolisian Negara Republik Indonesia terikat pada kode etik Profesi kepolisian Negara Republik Indonesia mengikat secara moral, sikap dan perilaku setiap anggota POLRI.

\section{Ucapan Terimakasih}

Terima kasih kepada tim pengelola Jurnal Ilmiah Ilmu Sosial (JIIS) yang telah memberikan kesempatan kepada penulis untuk mempublikasikan hasil kajian. Semoga artikel ini dapat memberikan manfaat bagi perkembangan ilmu pengetahuan terkait kewenangan diskresi aparat Kepolisian dalam memberikan pelayanan publik dalam penegakan hukum terhadap tindak pidana.

\section{DaftarRujukan}

Anshar, Ulil, R., Setiyono, J. (2020). Tugas dan Fungsi Polisi Sebagai Penegak Hukum dalam Perspektif Pancasila. Jurnal Pembangunan Hukum Indonesia, 2(3).

Aziz, N. M. (2011). Laporan Akhir Tim Pengkajian Hukum Tentang Format Kepolisian RI Di Masa Depan (Perbandingan Dengan Beberapa Negara). Kementerian Hukum Dan Hak Asasi Manusia Badan Pembinaan Hukum Nasional RI. Jakarta.

Faisol A. (2003). Diskresi Polisi Negara Republik Indonesia dalam Rangka Penegakan Hukum Pidana. Disertasi. Pascasarjana Universitas Diponegoro, Semarang.

Felisiano, I., Paripurna, A. (2010). Profesionalisme Polri Dalam Penerapan Wewenang Diskresi Dalam Kasus Tindak Pidana Pencurian (Studi Kasus Pencurian Kakao, Pencurian Biji Kapuk, Dan Pencurian Semangka). Yuridika, 25(3).

Guntur, M. (2017). Fungsi Kepolisian Negara dalam Pemeliharaan Keamanan dan Ketertiban Pada Masyarakat Kota Sengkang Kabupaten Wajo. Al-Hikam, 1(3), 64-78.

Haji, S., Gunarto, G. (2018). Implementasi Kewenangan Diskresi Kepolisian Dalam Penanganan Tindak Pidana Di Polres Demak Jawa Tengah. Jurnal Hukum Khaira Ummah, 13(1).

Kemal, D. (2015). Sosiologi Peradilan Pidana. Jakarta: Buku Obor.

Loraine, G., Nicola, P. (2003) Exercising Discretion Decision-making in the Criminal Justice System and Beyord. UK: Willan Publishing.

Mahrus, A. (2007). Paradigma Baru dalam P enggunaan Diskresi oleh Polisi dan Jaksa dalam Penegakan Hukum Pidana (Sistem Peradilan Pidana Progresif; Alternatif Dalam Penegakan Hukum Pidana. Disertasi. Pascasarjana FH UII, Yogyakarta.

Marzuki, P. M. (2005). Penelitian Hukum. Edisi Revisi. Jakarta: Penerbit Kencana Prenada. 
Najwan, J. (2010). Implikasi Aliran Positivisme Terhadap Pemikiran Hukum Inovatif. Jurnal Ilmu Hukum, 2(3).

Nugrahanto, Y. F. X. (2013). Kewenangan Diskresi Kepolisian Negara Republik Indonesia dalam Menentukan Rehabilitasi Pengguna Narkotika. Dissertation. Fakultas Hukum Universitas Atma Jaya, Yogyakarta.

Peraturan Kepala Kepolisian Negara Republik Indonesia Nomor 7 Tahun 2009 Tentang Sistem Laporan Gangguan Keamanan dan Ketertiban Masyarakat.

Priyantoko, G. (2017). Penerapan Diskresi Kepolisian Dalam Penanganan Unjuk Rasa. De Lega Lata: Jurnal Ilmu Hukum, 1(1), 109-136.

Pudi, R. (2007). Hukum Kepolisian: Profesionalisme dan Reformasi Polri. Surabaya: Laksbang Mediatama.

Raharjo, A., \& Angkasa. (2011). Profesionalisme Polisi Dalam Penegakan Hukum. Jurnal Dinamika Hukum, 11(3).

Said, A. (2012). Tolak Ukur Penilaian Penggunaan Diskresi Oleh Polisi Dalam Penegakan Hukum Pidana. Jurnal Hukum dan Peradilan, 1(1), 147-170.

Satjipto, R. (2006). Membedah Hukum Progresif. Jakarta: Kompas.

Satjipto, R. (2009). Penegakan Hukum, Suatu Tinjuan Sosiologis. Yogyakarta: Genta Publising.

Sidharta, B. A. (2008). Refleksi tentang Struktur Ilmu Hukum. Bandung: Mandar Maju.

Susanti, D. O., Efendi, A. (2014). Penelitian Hukum (Legal Research). Jakarta: Sinar Grafika.

Syamsudin, M. (2007). Operasional Penelitian Hukum. Jakarta: Raja Grafindo Persada.

Tasaripa, K. (2013). Tugas dan Fungsi Kepolisian daalam Perannya sebagai Penegak Hukum Menurut Undang-Undang Nomor 2 Tahun 2002 tentang Kepolisian. Jurnal Ilmu Hukum Legal Opinion, 1(2), 1-9.

Undang-Undang Dasar Negara Republik Indonesia Tahun 1945. (Lembaran Negara Republik Indonesia No. 75 Tahun 1959).

Undang-Undang No. 30 Tahun 2014 Tentang Administrasi Pemerintahan.

Undang-undang Nomor 2 Tahun 2002 tentang Kepolisian Negara Republik Indonesia. 